\title{
PROSPECTS FOR THE DEVELOPMENT OF SPA TOURISM IN ROMANIA
}

DOI: http://dx.doi.org/10.18509/GBP.2019.36

UDC: $338.48-53(498)$

Grecu Alexandra ${ }^{1,2}$

Drăghici Cristian Constantin ${ }^{1,2}$

Gruia Andreea Karina ${ }^{1,2}$

Teodorescu Camelia ${ }^{1,2}$

Dima Cristina ${ }^{3}$

${ }^{1}$ University of Bucharest, Faculty of Geography, Romani

${ }^{2}$ University of Bucharest - Research Center for Integrated Analysis and Territorial Management (CAIMT), Romania

${ }^{3}$ Bucharest Academy of Economic Studies, Department of Management, Romania

\begin{abstract}
Spa tourism has become a major sector of the international tourism market, which generates an increase in functional complexity at the level of local systems. Through an effective management policy and an appropriate marketing policy, this type of tourism can bring significant economic benefits with a positive impact on the territorial systems that have spa resources. Through the present study, we have proposed a diagnosis of the territorial systems that have important spa resources, at the level of the Romanian regions, based on statistical data offered by the National Institute of Statistics, National House of Public Pensions, as well as on economic data at territorial administrative unit level, with the main economic indicators. The methodology is based on the analysis of the two categories of statistical data on tourism, more specifically, those aimed on the evolution of available accommodation capacity, those targeting tourist flows (arrivals and overnight stays), data on the evolution of treatment tickets and data with the main economic indicators from the tourism sector. The obtained results show significant differences between spa resorts in Romania, differences determined by the level of investments made for both basic and tourist infrastructure.
\end{abstract}

Keywords: spa resorts, tourism, development perspectives

\section{INTRODUCTION}

Today, tourism is one of the most dynamic sectors of the world economy, with a positive trend in recent years. Worldwide, spa tourism is recognized as one of the oldest forms of tourism, practiced since antiquity and one of the subtypes of health tourism [1], where the impact generated by it is both directly, through income and employment, and indirectly [2].

Over time, spa tourism has become an important segment of the international tourism market due to its important social and economic effects. This type of tourism is also an economic component with a spectacular dynamics, the integrated analysis of this economic sector being a key element in understanding complex relationships [3], which give sustainability to local economies with specific resources.

Within the Romanian tourism industry, spa tourism represents a major sector due to its specific particularities, knowing that Romania owns 1/3 of Europe's thermal and mineral waters, its effects on health being attested over the centuries through an old tradition. 
The analysis of spa tourism in the development of local economies is important due to the complex economic influences [4], [5], [6], [7], both vertically and horizontally, in the economic system of local systems [8], [9], [10].

Spa tourism can be a viable alternative in this context and, at the same time, an economically efficient type of tourism that can maximize local economic benefits [11], [12].

\section{METHODOLOGY}

In the present study, a number of 32 spa resorts from Romania were analyzed, according to the Decision no. 926 of 2016, regarding the granting of the status of spa and balneoclimatic resort for some localities and areas that have natural spa resources. For these systems with spa resources, cartographic representations (using the open source QGis 3.4 software) were made to better understand their distribution in Romania, but also graphical representations using the data provided by the National Institute of Statistics and the National House of Public Pensions, for the following statistics: the tourist accommodation capacity in operation, arrivals of tourists in tourist accommodation structures and tickets for balneary and rest treatment provided by state social insurance.

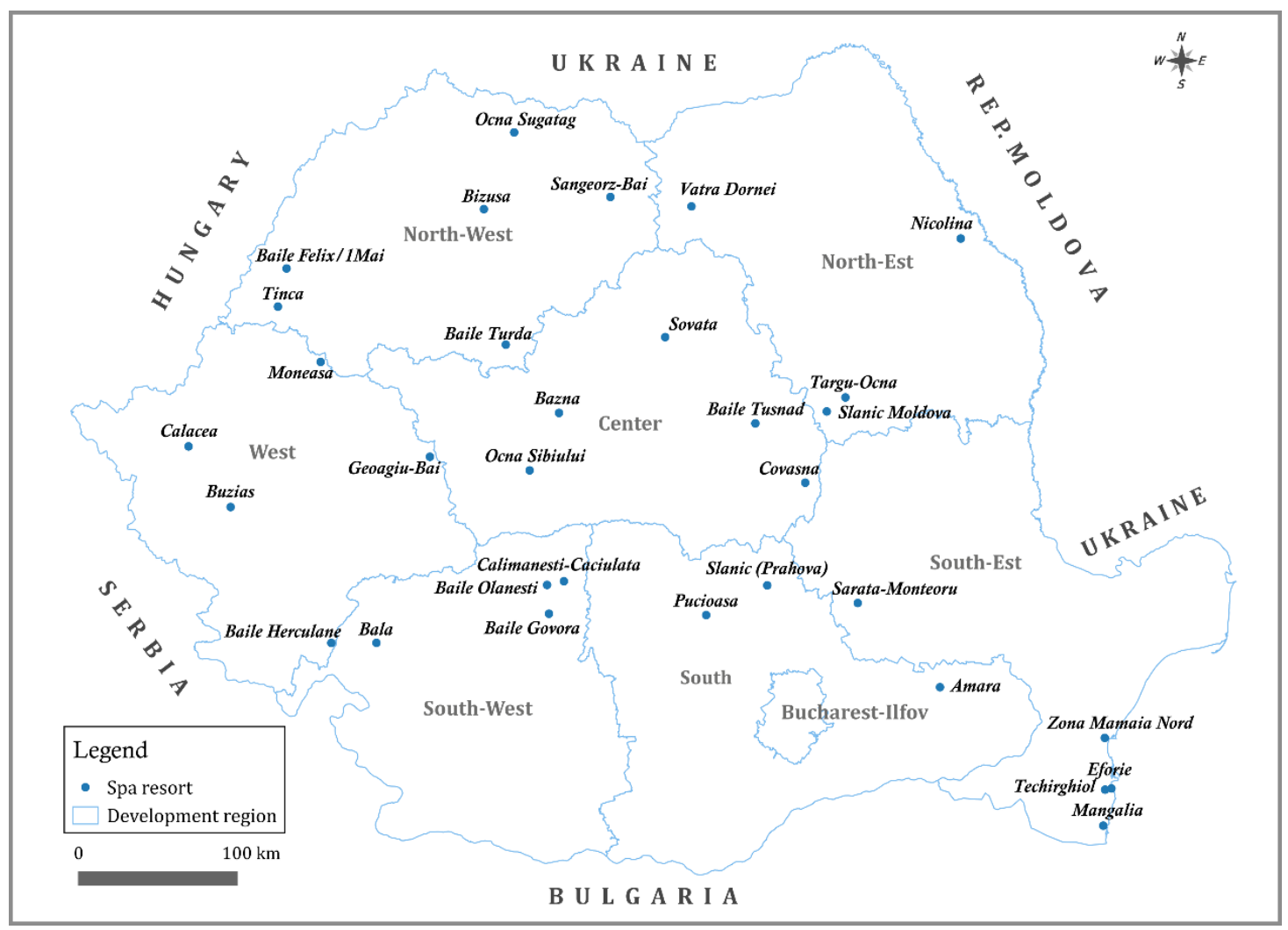

Figure 1. The distribution of spa resorts from Romania by development regions

\section{RESULTS}

\section{The situation of spa resorts at national level}

At national level, in terms of the evolution of accommodation capacity (accommodation that are actually available for tourists) (Fig. 2), there is a relatively steady evolution over the period 2000-2010, but with the global economic crisis, there is a sharp decline in this statistical indicator, with 33960 seats, about 26\%. The revival after the economic crisis is 
explained both by the emergence and development of new accommodation facilities, type of pension in the spas, and by the rehabilitation of some old hotels. The tourist flows from the resorts (Fig. 3), recorded significant fluctuations, with a significant decrease in the period 2008-2010 of 290,572 tourists, namely $21.2 \%$, the maximum number of tourists being reached in the last year of analysis. An immediate observation in the dynamics of treatment tickets is that they show a downward trend, with a drastic decrease during the world economic crisis. Although the number of treatment tickets is apparently very high, their share in the total arrivals from spa resorts is only $25 \%$ in the pre-crisis period, reaching $8 \%$ in the last year of analysis, 2017 (Fig. 4).

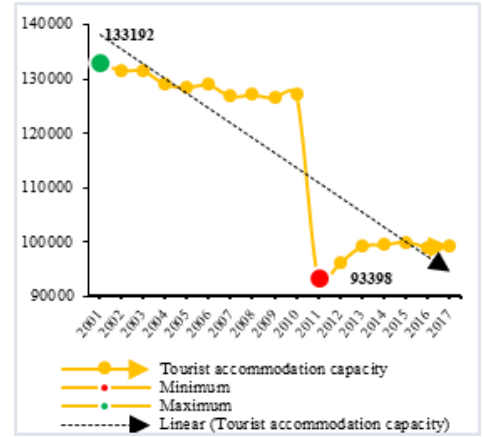

Figure 2. Tourist

accommodation capacity

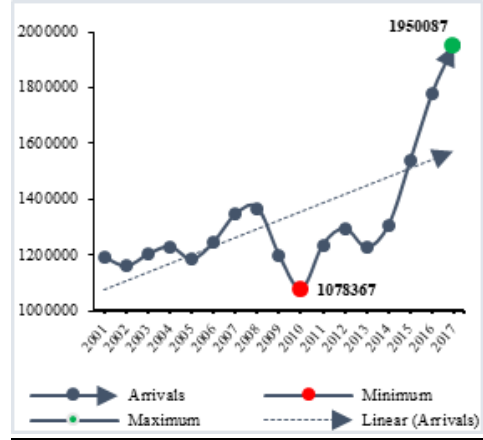

Figure 3. Arrivals of tourists in accommodation facilities

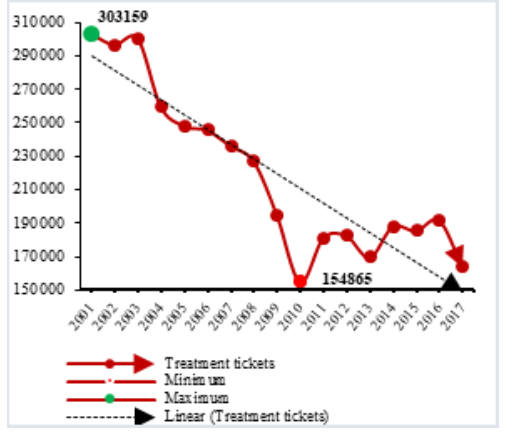

Figure 4. Spa treatment tickets

In the following, will be present the major developments in the spa sector for the period 2001-2017, at the level of each development region in Romania.

\section{North-East Region}

Available accommodation places for tourists in the North-East Development Region of Romania have a general trend of growth despite fluctuations present during all the analyzed period (Fig. 5). Thus, from 2001 until 2017, when the highest tourist accommodation capacity was registered, the number of seats increased by 3377 , in percentage meaning about $41 \%$. The tourist arrivals in this region have a general trend of growth, with a decrease of about 11\% (26,508 persons) between 2008 and 2010 (Fig. 6). The treatment tickets that were settled by the National House of Public Pensions (Fig.7), from Vatra Dornei, Nicolina (Hotel Nicolina), Târgu Ocna and Slanic Moldova, compared to the number of arrivals, are in full decline, the share held by these tickets from 2017 in the total tourist flow represents only $0.8 \%$.

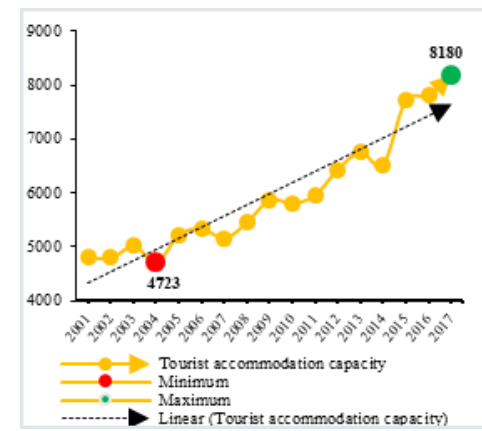

Figure 5. Tourist accommodation capacity

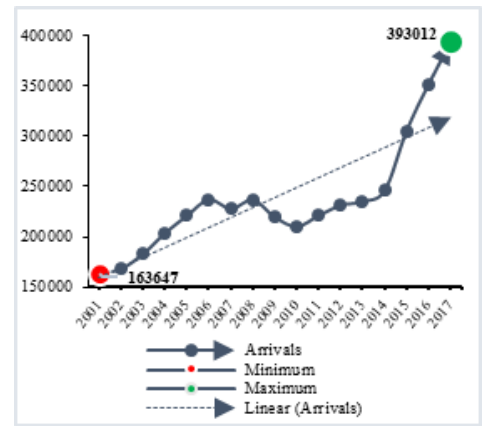

Figure 6. Arrivals of tourists in accommodation facilities

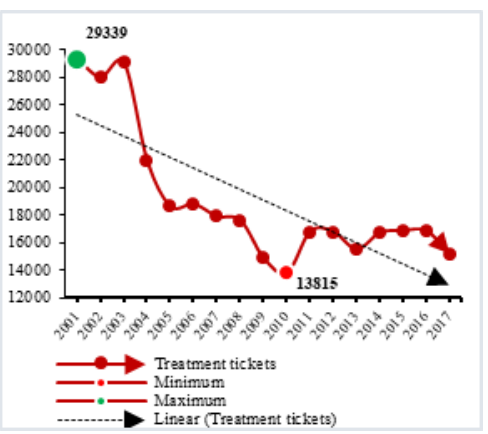

Figure 7. Spa treatment tickets 


\section{South-East Region}

The tourist accommodation capacity of the spa resorts in the South-Eastern region (Fig. 8), shows a drastic decrease from 2010 to 2011 by approximately $40 \%$, a decline that has occurred across the country, not just in spa resorts, followed by slight increases until 2014, then falling again. As in the case of the above-mentioned region, both, tourist arrivals (Fig. 9) and settled treatment tickets (Fig. 10) show the same trend, increase for the first indicator and decrease for the second indicator. In this case, the share held by the treatment tickets in the total tourist flow does not represent more than $2.2 \%$ in 2017 , compared to $9 \%$ in 2001.

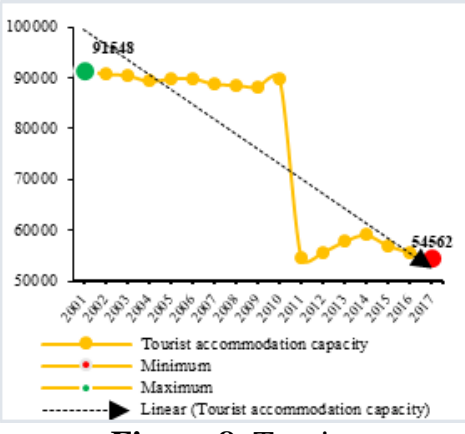

Figure 8. Tourist accommodation capacity

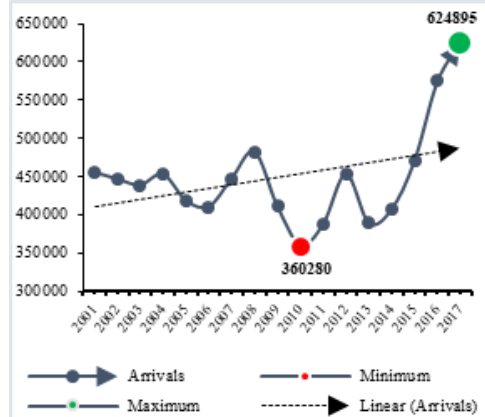

Figure 9. Arrivals of tourists in accommodation facilities

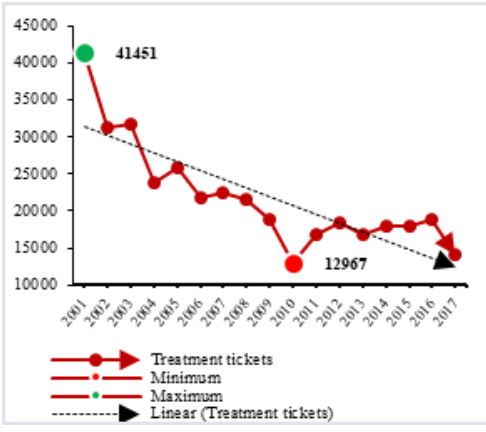

Figure 10. Spa treatment tickets

\section{South Region}

The Southern Region of Romania is the one with the lowest number of spa resorts in all development regions in the country, such as Amara, Slănic Prahova and Pucioasa. Although the accommodation conditions, provision of treatment bases and the quality of the services offered by these resorts, satisfies to a small extent the tourist requirements, they are rich in natural resources that can lead to a better development of spa tourism.

The Amara resort remains the main resort of the region, with an important touristic accommodation capacity of over $70 \%$ of all accommodation available to tourists, even during the economic crisis (Fig. 11). The tourist flow recorded important fluctuations during the reference period, reaching the maximum number of tourists in 2007, of 47278, where most tourists registered in the Amara resort - 26958, followed by Pucioasa, with 14587 tourists, and the last place, Slănic Moldova with only 5733 (Fig. 12).

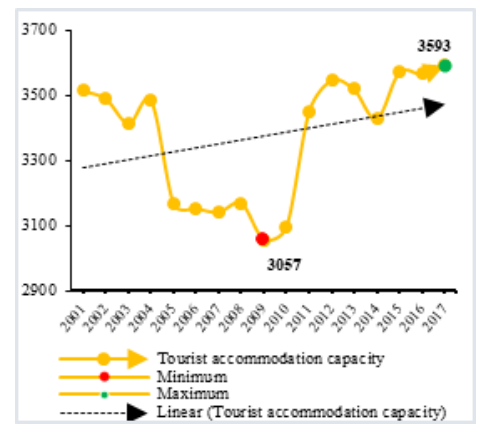

Figure 11. Tourist accommodation capacity

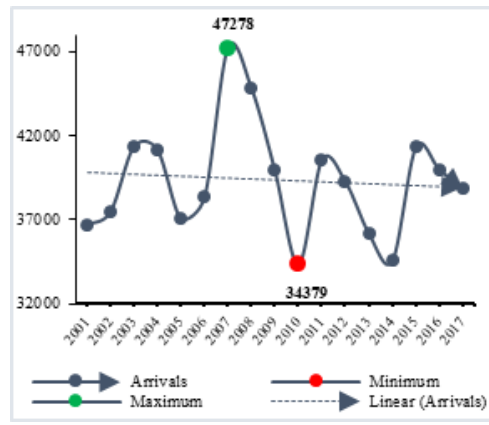

Figure 12. Arrivals of tourists in accommodation facilities

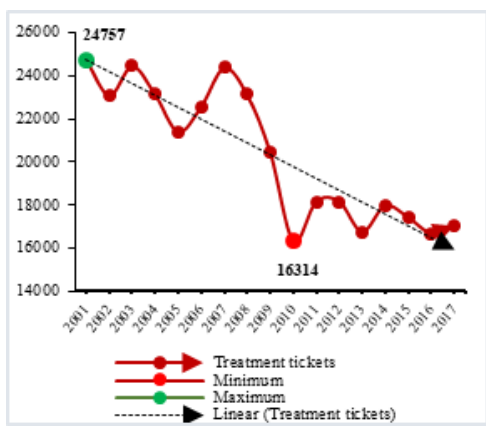

Figure 13. Spa treatment tickets

Of the maximum number of tourist arrivals in 2007, treatment tickets accounted $51.6 \%$, those for the Amara resort accounting more than half of the share. However, the situation 
changes, the year 2017 having a value for treatment tickets of the total arrivals lower by $8 \%$ (Fig. 13).

\section{South - West Region}

The evolution of tourist accommodation capacity in this region indicates two critical periods, 2004 and 2010 (Fig. 14), when the lowest values of this tourist indicator were recorded, 6487 seats, respectively 6637. The resorts where these decreases occurred were Băile Olănesti for the 2004 period (with a decrease compared to the previous about 14.2\%) and Băile Govora with Călimăneşti-Căciulata for the 2010 period (by 12.4\%, respectively $7.5 \%$ compared to the previous year). Tourist arrivals after 2013, show a significant increase, mainly due to two resorts, Băile Olăneşti and Călimăneşti-Căciulata (Fig. 15). This two resorts ranked first in tourist arrivals from the southwestern region because, according to NATA (National Association of Tourism Agencies), the preferences of families with children for holidays were hotels with Aqua Park, thermal pools and spa centers and these spa resorts have these facilities. In terms of treatment tickets, their trend is decreasing, accounting for only $16.4 \%$ of the total tourist flow in 2017 (Figure 16).

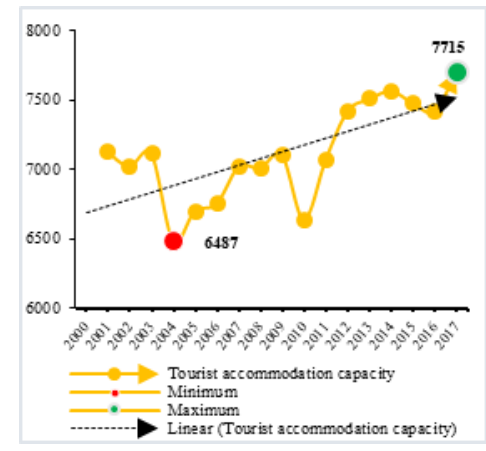

Figure 14. Tourist accommodation capacity

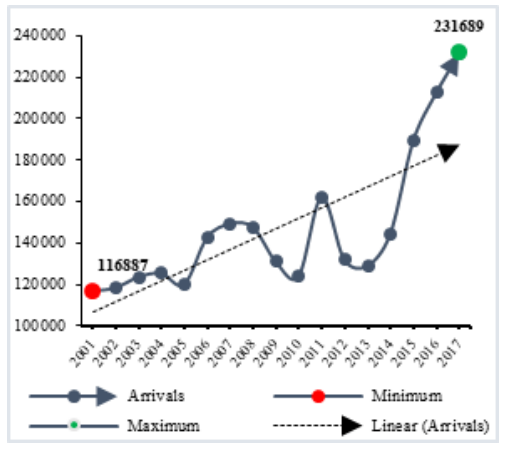

Figure 15. Arrivals of tourists in accommodation facilities

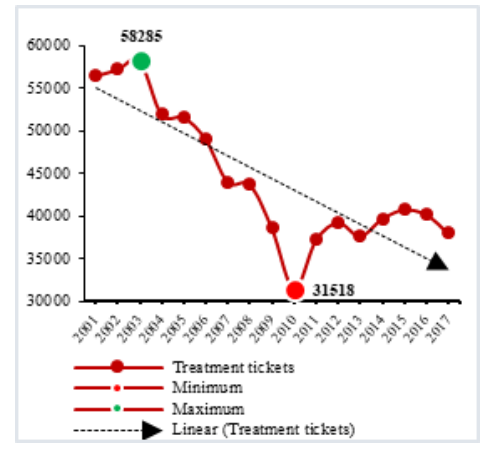

Figure 16. Spa treatment tickets

\section{West Region}

The tourist accommodation capacity of this area presents quite significant fluctuations, the most significant increase being in the period 2011-2013, when two hotels in the Băile Herculane resort were inaugurated (Hotel Diana and Hotel Afrodita), leading to an increase in the number of tourist accommodation places by approximately 60\% (Fig. 17). In the Western Region, the increase in the tourist flow in spa resorts (Fig. 18) is also influenced by Băile Herculane, which holds a fairly significant share in total, 45\% in 2011 and $58 \%$ respectively in 2017. The only resort in this development region that experienced significant decline of tourists during the growth period for the other resorts was Moneasa, where tourist activity is rather weak compared to others.

The treatment tickets, as in the other regions of Romania, shows a downward trend, so that, in the period of increase of tourists arrivals, they represented only 15-23\% (Fig. 19). 


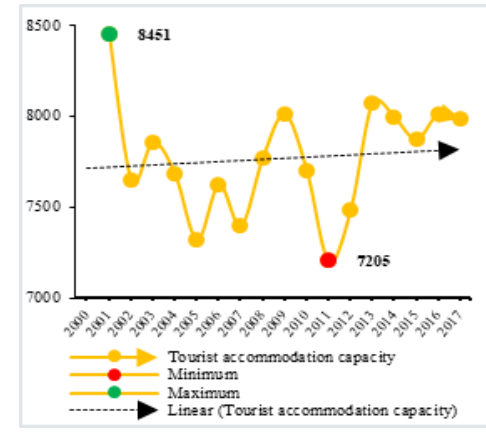

Figure 17. Tourist accommodation capacity

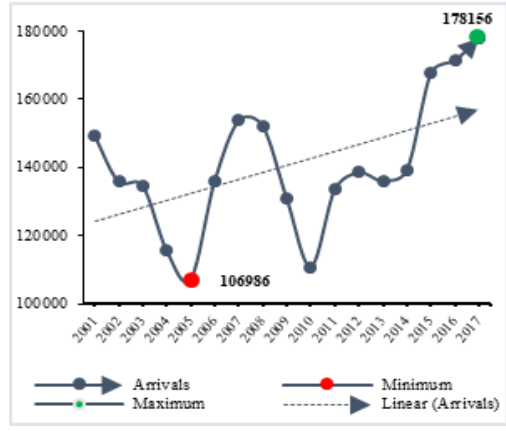

Figure 18. Arrivals of tourists in accommodation facilities

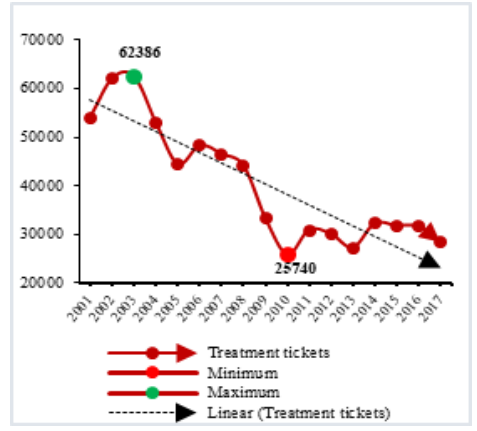

Figure 19. Spa treatment tickets

\section{North -West Region}

In the case of the Northwest of Romania, the accommodation capacity has been spectacularly increasing since 2015, mainly due to the inauguration of the only 5-star thermal complex on the territory of Romania, Lotus Therm Spa\&Luxury Resort from Băile Felix and by building new accommodation in the Ocna Şugatag resort (Fig. 20). Significant increases in the flow of tourists, with approximately 30\%, starting with 2015 (Fig. 21), were registered in Băile Felix Resort, due to the presence of the spa complex and in Băile Turda. Arrivals financed through treatment tickets also recorded strong declines in the period 2003-2010, followed by fluctuations, and then in 2017 they will be again in full swing (only 23804 tickets, ie $9.6 \%$ of total tourist arrivals in the last year of analysis) (Fig. 22).

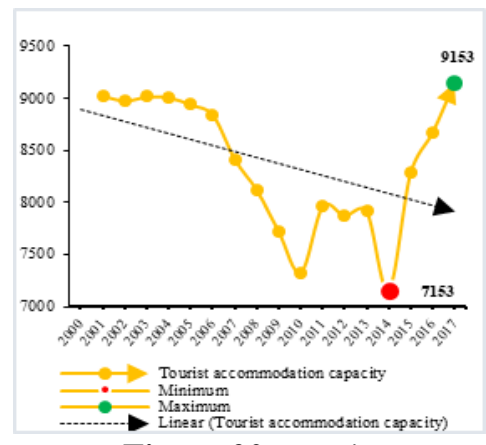

Figure 20. Tourist accommodation capacity

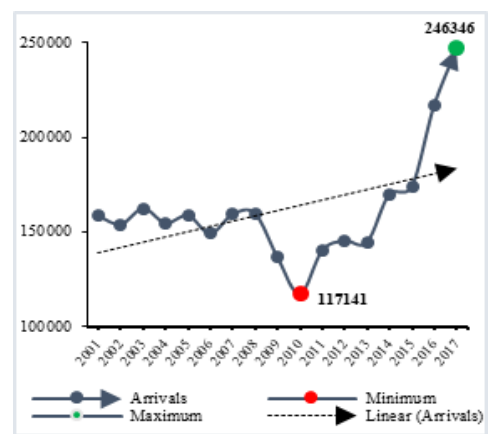

Figure 21. Arrivals of tourists in accommodation facilities

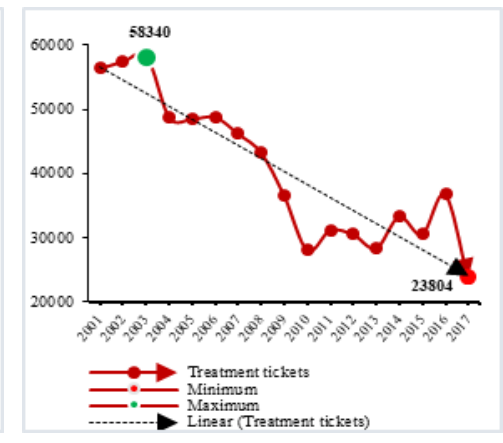

Figure 22. Spa treatment tickets

\subsection{Central Region}

The Central Region of the country represents the area with an important performance of spa tourism, where numerous investments have been made in the modernization of the spa infrastructure after the economic crisis (Sovata). The increase of the accommodation capacity in 2009, when the lowest value was registered, until 2017, it was made with about 20\%, namely with 1633 accommodation places (Fig. 23). Tourist arrivals start to increase spectacularly starting with 2014, in all resorts in this development region, especially in Băile Tuşnad, Covasna and Sovata, with about 33\% (Fig. 24). As in all analyzed development regions, also in this region the treatment tickets are on a downward trend, with a share of spa resort arrivals of only $12 \%$ compared to the first year of analysis when they represented 37\% (Fig. 25). 


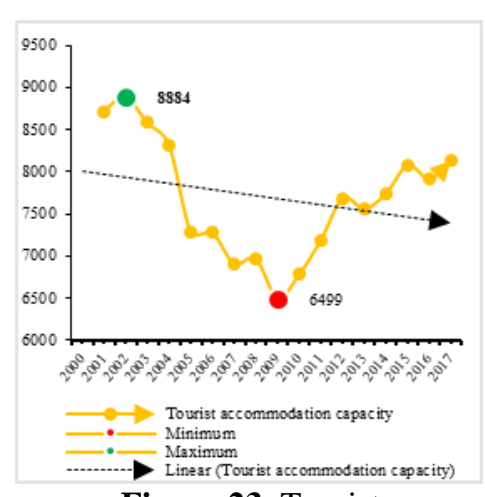

Figure 23. Tourist

accommodation capacity

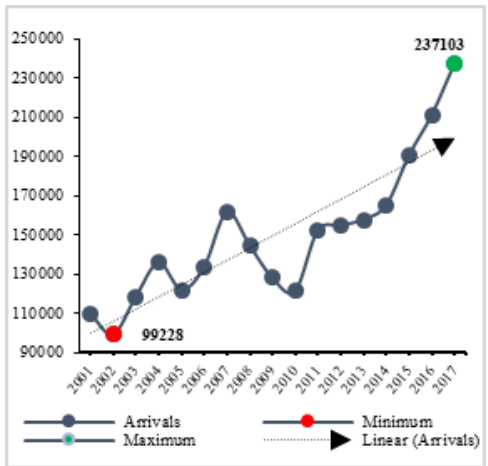

Figure 24. Arrivals of tourists in accommodation facilities

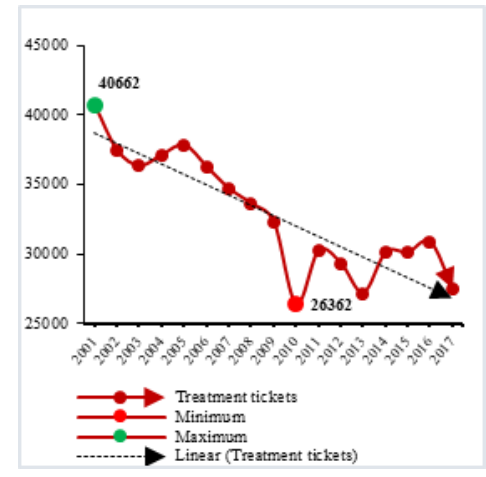

Figure 25. Spa treatment tickets

\section{CONCLUSIONS}

Enhancing the competitiveness and attractiveness of this regions as tourist destinations, depends largely on the provision of quality tourism in terms of accommodation and services. As a result of the analysis of the three statistical indicators, there was a differentiation of the regions depending on the existing spa systems at their level and also common features. Thus, if in the North-East, South-West, North-West and Center both the accommodation capacity and the arrivals of the tourists show a growth trend, due to the performance of spa tourism and the numerous investments in the modernization of the spa infrastructure, in the other regions, South-East, South and West, these indicators show numerous fluctuations, largely due to the problematic state of infrastructure and equipment, which do not satisfy the requirements of tourists. The third indicator, spa treatment tickets, registered a decreasing trend in all the development regions of Romania, the most important role being played by the legislative changes that affected the state social insurance budget.

In the context of sustained and targeted investments both to the development and diversification of tourism products and support infrastructure, regions can significantly improve their attractiveness and external perception [13].

\section{REFERENCES}

[1] Drăghici C. C., Diaconu D., Teodorescu C., Pintilii R. D. \& Ciobotaru A. M. Health tourism contribution to the structural dynamics of the territorial systems with tourism functionality, International Conference - Environment at a Crossroads: SMART approaches for a sustainable future, Procedia Environmental Sciences, vol. 32, pp 386 - 393, 2016.

[2] Global Spa \& Wellness Economy Monitor, 2014.

[3] Peptenatu D., Drăghici C., Stoian D., Pintilii R. D., Cercleux A. L., Merciu C. \& Schvab A. Qualitative changes in the entrepreneurial sector in emerging territorial systems - Craiova case study, Acta Geographica Slovenica-Geografski Zbornik, vol. 54, pp 293-304, 2014

[4] Kapczynski A. \& Szromek, A., R. Hypotheses concerning the development of Polish spas in the years 1949-2006, Tourism Management, vol 29, pp 1035-1037, 2008.

[5] Silva Gustavo N. A. 21st-Century Approach to Health Tourism Spas: The Case of Portugal, Journal of Hospitality and Tourism Management, vol. 17, pp 127-135, 2010.

[6] Perić G., Stojiljković M., Gašić M. \& Ivanović V. Perspectsives of development of spa tourism in Serbia, Journal of Awareness, pp 597-614, 2017. 
[7] Page J. S., Hartwell H., Johns N., Fyall A., Ladkin A. \& Hemingway A. Case study: Wellness, tourism and small business development in a UK coastal resort: Public engagement in practice, Tourism Management, vol. 60, pp 466-477, 2017.

[8] Ianos I., Peptenatu D., Pintilii R.D. \& Draghici C. About sustainable development of the territorial emergent structures from the metropolitan area of Bucharest, Environmental Engineering and Management Journal, vol. 11, pp 1535-1545, 2012.

[9] Peptenatu D., Pintilii R., Draghici C., Merciu Cristina \& Mateescu R. D. Management of Environment Risk within Emergency Territorial Systems. Case Study - the Influence Area of the Bucharest City, Journal of Environmental Protection and Ecology, vol. 13, pp 2360- 2370, 2012.

[10] Peptenatu D., Drăghici C. \& Merciu C. (2012). Characteristics of entrepreneurial profile in some emergent territorial structures in Romania, Actual Problems of Economics, vol. 12, pp 448458, 2012.

[11] Peptenatu D., Merciu C., Merciu G., Drăghici C. \& Cercleux L. Specific features of environment risk management in emerging territorial structures, Carpathian Journal of Earth and Environmental Sciences, vol. 7, pp 135-143, 2012.

[12] Braghină C., Peptenatu D., Drăghici C., Pintilii R. D. \& Schvab A. Territorial management within the systems affected by mining.case study the South-Western development region in Romania, Iranian Journal of Environmental Health Science \& Engineering, vol. 8, pp 315-324, 2011.

[13] Reactualizarea Master Plan pentru dezvoltarea turismului balnear (http://turism.gov.ro/web/wp-content/uploads/2017/02/Master-Plan-pentru dezvoltareaTurismului-Balnear_faza-I-si-II-ptr-PaginaWeb.pdf) 